\title{
Studies in Political Economy
}

\section{Series editor}

Norman Schofield, Washington University in Saint Louis,

Saint Louis, MO, USA 
More information about this series at http://www.springer.com/series/13366 
Norman Schofield • Gonzalo Caballero

Editors

State, Institutions and Democracy

Contributions of Political Economy

算 Springer 


\section{Editors}

Norman Schofield

Department of Political Science

Washington University in St. Louis

Saint Louis, USA

\author{
Gonzalo Caballero \\ Faculty of Economics \\ University of Vigo \\ Vigo, Spain
}

ISSN 2364-5903

Studies in Political Economy

ISBN 978-3-319-44581-6

DOI 10.1007/978-3-319-44582-3
ISSN 2364-5911 (electronic)

ISBN 978-3-319-44582-3 (eBook)

Library of Congress Control Number: 2016956209

(c) Springer International Publishing Switzerland 2017

This work is subject to copyright. All rights are reserved by the Publisher, whether the whole or part of the material is concerned, specifically the rights of translation, reprinting, reuse of illustrations, recitation, broadcasting, reproduction on microfilms or in any other physical way, and transmission or information storage and retrieval, electronic adaptation, computer software, or by similar or dissimilar methodology now known or hereafter developed.

The use of general descriptive names, registered names, trademarks, service marks, etc. in this publication does not imply, even in the absence of a specific statement, that such names are exempt from the relevant protective laws and regulations and therefore free for general use.

The publisher, the authors and the editors are safe to assume that the advice and information in this book are believed to be true and accurate at the date of publication. Neither the publisher nor the authors or the editors give a warranty, express or implied, with respect to the material contained herein or for any errors or omissions that may have been made.

Printed on acid-free paper

This Springer imprint is published by Springer Nature

The registered company is Springer International Publishing AG Switzerland 


\section{Contents}

Part I Bargaining, Lobbying and State Capture

Bargaining with Outside Options $\ldots \ldots \ldots \ldots \ldots \ldots \ldots \ldots \ldots \ldots \ldots \ldots \ldots, \quad 3$

Ken Binmore and Jon X. Eguia

Lobbying Mechanisms

Martin Gregor

Financial Sector Regulation and the Revolving Door in US

Commercial Banks

Elise S. Brezis and Joël Cariolle

Part II Democracy, Participation and Electoral Politics

The Rhetoric and Reality of Austerity: Electoral Politics

in Britain 2010 to 2015

Paul Whiteley, Harold D. Clarke, and Marianne Stewart

Valence and Ideological Proximity in the Rise of Nationalist

Parties: Spanish General Elections, 2008 and 2011

Elena Labzina, Joan Barceló, and Norman Schofield

Measuring Direct Democracy

Nadia Fiorino, Roberto Ricciuti, and Fulvio Venturino

Political Participation in Rural India: A Village Level Study

Vani K. Borooah and Anirudh Tagat

Elections with International Relations Dominance

Jan Klingelhöfer

Electoral Rules and Proportionality in Spain: Estimating

the Impact of some Swedish Rules Through the 2011 Electoral Data

Jose M. Pavia and Fernando Toboso 


\section{Part III State and Public Services}

Is There a Doctor in the House?

Jani-Petri Laamanen, Mikko Poutanen, and Katri Sieberg

What Makes People Nursing Home Residents: Individual Need or Municipalities' Supply?

Theis Theisen

Civil Service and the Crisis: A Comparative Analysis

of Iberian Countries (2008-2013)

Enrique José Varela-Álvarez,

Joaquim Filipe Ferraz Esteves de Araújo,

and Óscar Briones Gamarra

\section{Part IV Cases of Institutional Change}

Congressional Negotiations with Costly Voting: Understanding the Reforms to PEMEX in 2006-2008

Gilles Serra

Institutional Change, Specific Investments and Photovoltaic

Power Plants: The Empirical Effects of the Energy Policy

of "Solar Farms" in Spain

Marcos Álvarez-Díaz, Raquel Fernández-González, and Gonzalo Caballero

The Economic Effects of the Implementation of the Greek Adjustment Plan in the Great Recession

Inmaculada Carrasco, Carmen Córcoles, and John McCombie

E-Procurement and Innovation in the Portuguese

Municipalities: When Change Is Mandatory

Luís Soares and Adão Carvalho 


\section{Contributors}

Marcos Álvarez-Díaz is an associate professor at the University of Vigo (Spain). He holds a Ph.D., M.Ph., and M.A. in economics from Columbia University (New York, USA). He is the head of the research group on economic modeling and forecasting at the University of Vigo. His work has appeared in several economic journals such as Applied Economics, Economic Modelling, Tourism Management, Journal of Forest Economics, Ecological Economics, and Empirical Economics, among others. His main area of interest is centered on time series modeling and forecasting using nonlinear techniques.

Joan Barceló is a Ph.D. student at Washington University in St. Louis. His research focuses on the identification of the sources of differences in people's preferences and behavior in the political arena.

Joaquim Filipe Ferraz Esteves de Araújo, Ph.D. in Public Administration, University of Exeter, UK, is an Associate Professor of Public Administration, School of Economics and Management, University of Minho, Braga, Portugal. His interest subjects are Public Management, Public Sector Reform, Local Government, Governance, and Transparency.

Ken Binmore is a mathematician turned economist and philosopher. He was one of the pioneers in the revival of game theory in the 1970s and in experimental economics in the 1980s. He has contributed to bargaining theory, evolutionary biology, and the theory of justice. His books include Mathematical Analysis, Game Theory and the Social Contract, Natural Justice, and Rational Decisions. He is currently working on the latter topic. He is an emeritus professor of economics at UCL and holds honorary positions at LSE, Bristol, and Warwick universities. He is a fellow of the British Academy and of the American Academy of Arts and Sciences.

Vani K. Borooah, who was born in India, is emeritus professor at the University of Ulster having been professor in applied economics there from 1987 to 2014. After taking his Ph.D. in 1977 from the University of Southampton, he worked for the next 10 years as a senior research officer at the University of Cambridge's 
Department of Applied Economics and, concurrently, was a fellow of Queens College. He is a past president of the European Public Choice Society and of the Irish Economic Association and is also honorary professor of economics at the University of Queensland. He was elected a member of the Royal Irish Academy in 2006. His work has been mainly in the areas of unemployment, inequality, poverty, and economic development.

Elise S. Brezis, professor of economics at Bar-Ilan University, is the head of the Aharon Meir Center for Banking and Economic Policy in Israel. She previously was the head of the statistics division at the Research Department in the Bank of Israel. She holds a Ph.D. in economics from MIT (USA). She has taught at the Sloan School of Management (MIT) and Brandeis and has been a visiting professor at the College de France as well as in South Korea. Her research interests cover a wide range of topics related to economic growth, from R\&D to higher education and human capital. She is currently working in the field of elites and economic growth, as well as on the revolving door. She has published articles in leading journals as the American Economic Review and the European Economic Review. In the field of economic growth, she has developed a theory, coined leapfrogging with the Nobel Laureate Paul Krugman.

Oscar Briones holds a bachelor's degree in political science and sociology and a Ph.D. in "contemporaneous political process" from the University of Santiago de Compostela (Spain). Currently, he is a lecturer at the School of Social Sciences and Communication (University of Vigo), where he teaches political science and public administration at the University of Vigo, and in the master's degree in public administration and institutional leadership. He is also a researcher at the Governance Lab G (Political Science and Public Administration, University of Vigo, Spain) that works on management and public services and governance. He is author of numerous publications in topics such as human resources, negotiation, public policy, and direction and leadership.

Gonzalo Caballero is an associate professor of economics at the University of Vigo, Spain. He received a Ph.D. and a B.Sc. in economics with honors from the University of Vigo and a Ph.D. in political science from the University of Santiago de Compostela. He has been a visiting scholar at the Center for New Institutional Social Sciences, Washington University, in St. Louis, the Center for Advanced Studies in the Social Sciences (Juan March Institute, Madrid), the University of California in Santa Barbara, and the University of California in Berkeley. He has been a visiting professor at Charles University (Prague, Czech Republic), Comenius University (Bratislava, Slovakia), the University of Valencia (Spain), Universita Roma Tre (Italy), Tallinn University of Technology (Estonia), the University of Granada (Spain), and the University of Oulu (Finland). He has published over 50 papers on institutional analysis and political economy in journals such as Economic Modelling, Journal of Institutional Economics, Ecological Economics, Ocean \& Coastal Management, Marine Policy, Environmetrics, Aquaculture Research, Forest Policy and Economics, Trimestre Económico, Brazilian Journal of Political 
Economy, Política y Gobierno, Revista de Estudios Políticos, Economic Analysis Review, Revista Española de Investigaciones Sociológicas, Perfiles Latinoamericanos, CLAD Reforma Democracia, and Revista Española de Ciencia Política, among others. He has written several books and recently coedited five volumes: Political Economy of Institutions, Democracy and Voting (Springer, 2011, with Norman Schofield), Nuevo Institucionalismo: Gobernanza, Economía y Políticas Públicas (CIS-Madrid, 2013, with Xosé Carlos Arias), Advances in Political Economy: Institutions, Modeling and Empirical Analysis (Springer, 2013, with Norman Schofield and Daniel Kselman), Democracia y Políticas Económicas (Síntesis, 2015, with F. Toboso), and The Political Economy of Governance (Springer, 2015, with Norman Schofield)

Joël Cariolle received his Ph.D. from the CERDI-University of Auvergne (Clermont-Ferrand, France) and is a research fellow at the Foundation for Studies and Researches on International Development (Ferdi, Clermont-Ferrand, France). His work focuses on the political economy of corruption in developing and developed countries, on economic vulnerability in least developed countries, and on regional integration in sub-Saharan Africa. Joël Cariolle also provides technical assistance and coordinates research at FERDI on regional integration in WAEMU and CEMAC areas.

Inmaculada Carrasco is a lecturer of the Economic Policy Unit in the University of Castilla-La Mancha. Holder of a Ph.D. in economics with European mention (1997), since 1991 she has taken up different positions as university teacher. She has a wide experience teaching economic policy subjects (four 5-years periods), and she teaches master's in sustainable economic growth and development. She has taken part in several national and international research groups. Of note is her participation in the Global Entrepreneurship Monitor Project. Her papers have been published in several international journals and monographs. She has been recognized with three 6-years researching terms. Her research has focused on different topics related to economic growth and entrepreneurship such as the study of the relationships among entrepreneurship and economic growth with an ethical point of view, the social economy institutions' entrepreneurial activity, gender and entrepreneurship, and some other aspects related to economic policy.

Adão Carvalho is an assistant professor of economics at the Department of Economics of the University of Evora, Portugal. He is the director of the master's program in public policy and projects at the University of Evora. He has a background in economics and received his Ph.D. in science and technology policy studies from the University of Sussex, UK, in 2002. His research focuses on innovation; science and technology policy; economics of knowledge, with an emphasis on R\&D expenditures and R\&D policy; and electronic public procurement (e-procurement), with a focus on organizational innovation in municipalities.

Harold D. Clarke is Ashbel Smith Professor, University of Texas at Dallas, former director of social and economic sciences at the National Science Foundation and senior editor of electoral studies. A former principal investigator of the British and 
Canadian national election studies, he has coauthored numerous books and articles on voting and elections including Affluence, Austerity and Electoral Change in Britain (Cambridge University Press, 2013), and Austerity and Political Choice in Britain (Palgrave Macmillan, 2015).

Carmen Córcoles graduated in 1991 in economics and business from university of Alicante with distinction and received her Ph.D. from the University of CastillaLa Mancha (UCLM) in 1997 (best doctoral thesis in public economics, award by Instituto Estudios Fiscales of Spain). Since, 1991 she has taken up different professor positions, and from 2000, she is lecturer of the Economic Theory Unit at the Faculty of Economics and Business in Albacete (UCLM). She has a wide experience teaching different economic theory subjects in degrees of economic and business administration and she also teaches at master's in sustainable economic growth and development. Her research has focused on impact economic analysis for countries and regions with input-output analysis. She has participated in several research projects on this topic, among which we can highlight the estimation of input-output tables of Castilla-La Mancha by indirect methods for Consejo Económico y Social (CLM), the estimation of oil derivative demand for the Spanish National Commission of Energy, and the computable general equilibrium model applied to $\mathrm{CO}_{2}$ emission calculations for the Spanish economy. From 2000, she is vice-dean at the Faculty of Economics and Business in Albacete.

Jon X. Eguia is an associate professor of economics at Michigan State University, with secondary affiliation to the University of Bristol. He obtained his Ph.D. from the California Institute of Technology in 2007. His fields of specialization are political economy and microeconomic theory. His work on party formation, voting and elections, and information aggregation in financial markets has been published in journals such as the Journal of Political Economy, the American Journal of Political Science, Games and Economic Behavior, or the Journal of Politics, among others.

Raquel Fernández-González is a postdoctoral fellow at the University of Vigo. She received a extraordinary award by her Ph.D. dissertation at the University of Vigo. Her work has been published in Marine Policy and Revista Española de Ciencia Política.

Nadia Fiorino is currently associate professor at the University of L'Aquila, where she has been teaching public finance and local public finance since 2001. She received a Ph.D. in economics from the University of Rome "La Sapienza." Her main areas of research are public choice/political economy, public finance, law and economics. She has published in numerous international peer-reviewed journals in economics, such as Public Choice, International Review of Law and Economics, and the Journal of Institutional and Theoretical Economics among others.

Martin Gregor is associate professor in economics at the Faculty of Social Sciences, Charles University in Prague. His main research fields are applied game theory, microeconomic theory, political economics, and organizational economics. 
He has published both in economics (Journal of Economic Behavior \& Organization, Economics Letters, International Tax and Public Finance, Review of Economic Design, The B.E. Journal of Theoretical Economics, Applied Economics) and political science (Journal of Theoretical Politics). Currently, he serves as director of the Institute of Economic Studies at Charles University in Prague, Czech Republic.

Jan Klingelhöfer is a postdoctoral fellow at RWTH Aachen University in Germany. $\mathrm{He}$ completed his Ph.D. in economics at the Institute for International Economic Studies in Stockholm in October 2010 and spent 1 year as a Max Weber Fellow at the European University Institute in Florence. His research interests are political economics and macroeconomics.

Jani-Petri Laamanen is a university lecturer in economics at the University of Tampere, Finland. He received his doctorate in economics from the same university. During his doctoral studies, he spent an academic year as a visiting researcher at the Tinbergen Institute Amsterdam. His research interests fall within empirical public and labor economics. Among other things, he has worked on the effects of healthcare costs on well-being, tax reporting, the relationship between home ownership and the labor market, and economic growth and subjective well-being.

Elena Labzina is a doctoral student in political science at Washington University in St. Louis. A native of Moscow, she holds a B.Sc. in applied math and computer science from Lomonosov Moscow State University (2007) and an M.A. in economics from New Economic School in Moscow (2010). Also, she took an M.A. in political science from the Central European University in Budapest in 2011. Her research interests include applied game theory, big data, and statistical methods.

John McCombie is professor of regional and applied economics in the Department of Land Economy and director of the Cambridge Centre for Economic and Public Policy at the University of Cambridge, UK. He is fellow and director of studies of economics and land economy at Downing College, Cambridge. He was a founding coeditor of the journal Spatial Economic Analysis. He is a fellow of the Regional Studies Association and fellow of the Academy of Social Sciences. He has previously held positions as a specialist advisor to the House of Lords on the European Union Committee Inquiry into the EU Structural and Cohesion Funds, and as an economic consultant to the World Bank and Asian Development Bank. His research interests are regional economics, the causes of regional and national growth rate disparities, economic growth and the balance-of-payments constraint, and economic methodology. He has published widely in such journals as the Economic Journal, Oxford Economic Papers, Urban Studies, the Cambridge Journal of Economics, Metroeconomica, and the Journal of Post Keynesian Economics. His most recent book, written with Jesus Felipe, is entitled The Aggregate Production Function and the Measurement of Technical Change (2013).

José M. Pavía is Quantitative Methods Full Professor at the Department of Applied Economics, University of Valencia, Spain. He is also the director of the "Elections and Public Opinion Research Group" of this University. His areas of interest are 
diverse and they comprise political issues, election forecasting, statistical (machine) learning, spatial statistics, and sampling. His main research has been published in journals such as Journal of the American Statistical Association, Environment and Planning A, Journal of the Royal Statistical Society, The Political Quarterly, or Revista Española de Investigaciones Sociologicas and he has served as visiting research in many universities, including Stanford, Leicester, Durham or Carlos III de Madrid.

Mikko Poutanen is a Ph.D. student and a doctoral researcher at the School of Management at the University of Tampere, Finland, where he also received his master's degree. His research interests are multidisciplinary, including the politics of welfare states and the influence of economic rationale and assumptions on political decision-making. Poutanen currently teaches courses on qualitative research methods. While his primary research language is English, he has also written on international security issues in Finnish in a refereed article.

Roberto Ricciuti is Associate Professor of Economic Policy at the University of Verona (Italy) where he is the Director of the Ph.D. program in Economics and Management. He holds an M.Sc. in Economics from the University of Exeter and a Ph.D. in Economics from the University of Siena (Italy). Previously he was a Lecturer at Royal Holloway University of London (2003/2004), a postdoctoral fellow at the University of Siena (2004/2005), and a Lecturer at the University of Florence (2005/2011). He is also a Research Fellow at CESifo and Honorary Professorial Fellow at the Effective States and Inclusive Development Research Centre at the University of Manchester. He works at the boundaries between economics and political science. His papers have been published on Journal of Peace Research, Public Choice, Journal of Economic Behavior and Organization, Cliometrica, European Journal of Political Economy, Defence and Peace Economics, and International Review of Law and Economics, among others.

Norman Schofield is the Taussig Professor in political economy at Washington University in St. Louis. He has published numerous articles and books in this field and holds Ph.D. degree in economics and political science from Essex University, a Litt. D. from Liverpool University, and a D.Sc. from the University of Caen.

Gilles Serra is assistant professor of politics at CIDE in Mexico. Before coming to CIDE, he earned his Ph.D. degree in political economy and government from the University of Harvard, and he was postdoctoral fellow at Nuffield College at the University of Oxford. His research on Mexican institutions, elections, and reforms has been published in Electoral Studies, the Journal of Politics in Latin America, and Política y Gobierno. His formal models of political parties and electoral competition have appeared in the Journal of Politics and the Journal of Theoretical Politics.

Katri Sieberg is a professor in the School of Social Sciences and Humanities at the University of Tampere in Finland. Her research combines approaches from economics and political science to address issues of how and why things work-or don't work. To that end, her research applies game theory and social choice theory 
to address how people make decisions, game theory and economics to assess the effect of these decisions, and experimental economics to evaluate the underlying theories. One of her key interests is welfare state institutions, with a strong focus on health-care economics.

Luís Soares is a highly experienced professional in Public Administration matters having followed closely the changes in "Public Procurement" model, from a strategic perspective particularly focused on procurement, contracting and strategic sourcing. For that effect in 2011 was appointed Head of a Multidisciplinary Team having coordinated and managed, since then, several areas, namely e-procurement, public policies, projects and economic development. Recently at the University of Evora (PT) he finished a Masters degree on Public Policies and Projects. His research, study and interests aim essentially public procurement in carrying out public policies through the European structural investment funds in a relational and holistic approach.

Marianne C. Stewart is professor in the School of Economic, Political and Policy Sciences at the University of Texas in Dallas. A former principal investigator for the British Election Study, her research interests include voting and elections in Canada, Great Britain, and the United States and public opinion dynamics in mature democracies. She has published widely in leading political science journals and her most recent book is Austerity and Political Choice in Britain (London: Palgrave Macmillan, 2015).

Anirudh Tagat is research author at the Department of Economics, Monk Prayogshala, Mumbai. Anirudh holds an M.Sc. in economics from the University of Warwick and consults with the World Resources Institute (WRI) India and Institute of Rural Management, Anand (IRMA). His research interests include cross-cultural differences in decision-making, intra-household bargaining, and experimental economics.

Theis Theisen is professor of economics at the Department of Economics and Finance, School of Business and Law, University of Agder. He has previously worked as director of budget and finance in Aust-Agder County and as consultant in the Norwegian Ministry of Finance. He has also served as member of the board of directors of several private companies and public sector organizations.

Fernando Toboso is professor at the Department of Applied Economics, University of Valencia, Spain. He received his degree in Economics with honors in 1985 and his Ph.D. in Economics in 1990 after spending an academic year at the Public Choice Center, George Mason University, USA. His research interests mainly are in methodological and epistemological issues in economic analysis, and in the organization of policy tasks in federal countries. Special attention is paid to the economic consequences of political and fiscal quasi-federalism in Spain as well as to the influences of different electoral institutions and rules. In all these areas he has authored several articles that have been published in English journals such as the Cambridge Journal of Economics, the Regional and Federal Studies, the History 
of Economic Ideas, the European Journal of Law and Economics and the Journal of Interdisciplinary Economics, among others. He has also published widely in Spanish academic journals and has contributed with several chapters to Spanish collective books as well as to English ones such as Oppenheimer et al. (2004, M.E. Sharpe), Williams (2005, Sage Publ.), Schofield et al. (2011, Springer). He has served as invited editor for two special issues in economic journals (Economic Analysis Review, Chile and Revista Asturiana de Economía, Spain). He was also an invited participant, together with Elinor Ostrom, Claude Menard and several other colleagues, to the workshop in honor of the career of Allan Schmid at Michigan State University with a paper that appeared in Batie et al. (2008, Routledge).

Enrique J. Varela, Ph.D. in Government and Public Administration (Ortega y Gasset University Research Institute and the Universidad Complutense of Madrid, Spain), is a Lecturer at the Faculty of Social Sciences and Communication (University of Vigo), where he teaches Political Science and Public Administration at the University of Vigo, Bachelor's Degree in Public Management and Master's Degree in Public Management and Institutional Leadership. He is also an academic coordinator and researcher at the Governance $\mathrm{Lab} \mathrm{G}^{3}$ (Political Science and Public Administration, University of Vigo, Spain) that works on management and public services and governance at local and cross-border level, on which he has published numerous contributions.

Fulvio Venturino obtained his Ph.D. in Political Science from the University of Florence, and at present is Associate Professor at the University of Cagliari. His preferred fields of research are party politics and voting behaviour. He was a member of the Scientific Board of the Italian Society for Electoral Research (SISE) between 2005 and 2010, and is now member of Itanes (Italian National Electoral Studies). In 2011 he launched Candidate and Leader Selection (www.cals.it), a standing group of the Italian Political Science Association (SISP). Recently he has published various book chapters and journal articles on the issue of intra-party democracy in Italy from a comparative perspective.

Paul Whiteley is a professor of government at the University of Essex. His research interests include electoral behavior, public opinion, political parties, political economy, and methodology in the social sciences. He is a fellow of the British Academy and a fellow of the Academy of Social Sciences. He is the author or coauthor of 18 academic books including studies of electoral behavior, party members, and citizenship in Britain. He was director of the Economic and Social Research Council Research Programme on Democracy and Participation from 1998 to 2003 and was the codirector of the British Election Study from 2001 to 2012. He has acted as an academic advisor to the Home Office, to the Department of Education, and to the Speaker of the House of Commons on issues relating to citizenship, participation, and Parliamentary representation. He frequently comments in the media on issues relating to elections and public opinion. 


\section{Introduction}

The state, institutions, and democracy are a central part of the research agenda of contemporaneous political economy. Politics and economics are interested in understanding the state, institutions, and democracy from an interdisciplinary approach in social science that combines modeling, mathematics, and econometrics with solid theoretical foundations, structural factors, political and economic history, applied studies, and institutional analysis. We are trying to open the "black box" of the state, the institutions, and the democracy in a research program that incorporates diverse types of analysis. Theoretical and applied contributions have been included to improve our knowledge of the issues that have been selected.

This volume includes contributions from authors of papers that were presented at the IV Conference on Political Economy and Institutions, held in Baiona, Spain, December 2015, under the auspices of the University of Vigo and Washington University in St. Louis. Moreover, other chapters have been invited to be included in this volume too. The result is a volume with contributions by economists and political scientists from Europe, America, and Asia. Of course, each chapter in this book went through a review process before publication.

The volume is structured in four parts. Part I presents three chapters on bargaining, lobbying, and state capture. Part II presents six chapters that study elections and voting. Part III includes three chapters on state and public services. Part IV presents four cases of institutional change. Below, we briefly sketch the topics discussed in these chapters.

\section{Part I: Bargaining, Lobbying and State Capture}

1. "Bargaining with Outside Options," Ken Binmore (University of Bristol) and Jon X. Eguia (Michigan State University)

This chapter comments on noncooperative and cooperate approaches to distributive (divide-the-cake) bargaining. We first review the challenges addressed by the seminal literature on two-person bargaining and three-person bargaining. 
We then explore more recent developments on dynamic multiplayer bargaining over distributive policies, both over a single decision and over an infinite sequence of decisions with an endogenous outside option.

2. "Lobbying Mechanisms," Martin Gregor (Charles University in Prague)

The Lobbying Disclosure Act 1995 has generated relatively clean data on the salaries of lobbyists and their staff, which has revolutionized the landscape of the analysis of political influence of special interests. This chapter reviews how the economic theory has reflected the recent shift of attention from campaign contributions to informational lobbying. The survey is an attempt to review the theoretical developments that are relevant to modeling of informational lobbying with explicit informational and game-theoretic microfoundations. The first part covers the early models of influence of special interests and discusses attempts to build explicit informational microfoundations for rentseeking contests. Next, the single-tool (payments or information) and multipletool (payments and information) models of influence are covered. Then, the latter models are broadly divided into lobby-and-pay models and pay-andlobby models. Specific yet important theoretical questions, namely, variants of information transmission, participation, and interaction of instruments of influence, are covered in detail .

3. "Financial Sector Regulation and the Revolving Door in US Commercial Banks," Elise S. Brezis (Bar-Ilan University) and Joël Cariolle (FERDI)

This chapter develops an index of the distortions due to the revolving doorthe Revolving Door Index. This index focuses on the process by which these distortions arise, by measuring the concentration of revolving door movements among private firms. We motivate this index, through a literature review and a small theoretical model, and illustrate it by an empirical application using data on the five biggest US commercial banks. Our data show that there is a concentration of revolving door movements which mainly benefit Goldman Sachs. This index may have policy implications for improving financial sector regulation.

\section{Part II: Democracy, Participation and Electoral Politics}

4. "The Rhetoric and the Reality of Austerity: Electoral Politics in Britain 2010 2015," Paul Whiteley (University of Essex), Harold D. Clarke (University of Texas in Dallas), and Marianne Stewart (University of Texas in Dallas)

The Conservative victory in the 2015 general election in Britain was a surprise since the polls indicated that a hung Parliament was the most likely outcome with no party having an overall majority. The analysis in this paper confirms the proposition that electorates reward an incumbent party for a good economic performance and punish it for a bad one. Thus, public perceptions of the state of the economy played a key role in explaining the election victory. However, the story is not a straightforward one since we argue that the initial 
economic policy adopted by George Osborne when he became Chancellor of the Exchequer in 2010 would have almost certainly lost the election for the Conservatives had he not changed course in the middle of the Parliament. The initial policy of austerity was adopted for ideological, theoretical, and electoral reasons but then was effectively abandoned midterm when it failed to stimulate an economic recovery. The paper shows how austerity was defined and pursued and how the government changed strategy in 2012 allowing a recovery from recession to take place. This in turn stimulated economic optimism among the voters which subsequently translated into an election victory in 2015.

5. "Valence and Ideological Proximity in the Rise of Nationalist Parties: Spanish General Elections, 2008 and 2011,” Elena Labzina, Joan Barceló, and Norman Schofield (Washington University in St. Louis)

This chapter investigates the rise of nationalist parties from the Spanish National Elections from 2008 to 2011 by adjusting the classic spatial voting framework. The traditional spatial analysis would suggest that stronger nationalistic preferences and nationalistic voters, party alignment might explain the increase in support for these parties. We argue that the rise of small and nationalist parties can hardly be explained by policy or nationalistic preferences given the spatial understanding of the politics.

Instead, exogenous valence is the main explanation for the electoral success of the political parties. This paper compares party valences and ideological, and demographic effects on the voting shares in the 2008 and 2011 Spanish National Elections to test our hypotheses. To properly capture the variation in the parties across regions, this paper develops and employs a refinement of the Bayesian adaptation for the varying choice logistic model proposed by Yamamoto (2011). Our findings suggest that the rise of the nationalist parties parallels the rise of the new political parties and not necessarily a shift in nationalistic preferences. Furthermore, we find that the main driver of the shifts in the electoral success across parties and regions is the changes in party-region exogenous valence. This paper provides important implications for the relevance of the non-policy considerations in the understanding of the changes in party support.

6. "Measuring Direct Democracy," Nadia Fiorino (University of L'Aquila), Roberto Ricciuti (University of Verona and CESifo), and Fulvio Venturino (University of Cagliari)

This chapter provides an empirical analysis aimed at uncovering the economic, political, and social variables that make direct democracy institutions more or less likely. We provide a framework to investigate direct democracy institutions along the lines of constitutional design proposed by Aghion et al. (2004). We analyze a unique dataset where 87 countries are classified through an index of direct democracy (DDI). In applying a number of estimation techniques, we find that direct democracy is mainly correlated with income and education and does not significantly relate to institutional variables like presidential system and majoritarian voting rules. 
7. "Political Participation in Rural India: A Village-Level Study," Vani K. Borooah (University of Ulster) and Anirudh Tagat (Department of Economics, Monk Prayogshala, Mumbai)

This chapter uses village-level data on individual voters to study the factors which determine the probability of whether an individual votes. Is this probability greater for national compared to local elections? And is there evidence that people are more likely to vote today than they were in the past? Allied to these questions is another set of questions relating to the choice of candidates. Needless to say, voting in elections is just one facet of political participation. Another might be attending and participating in political meetings. This is particularly relevant in Indian villages since the Constitution (73rd Amendment) Act of 1993. This made it mandatory for all villages to have a village council (hereafter, Gram Sabha) consisting of all registered voters on the electoral roll of a village. The Gram Sabha was to be entrusted with the power of supervising the functioning of the elected village panchayat and to approve the panchayat's development plan for the village and the associated budget. Consequently, in addition to voting, electors in villages had another form of political participation: they could attend Gram Sabha meetings and also participate in its discussions. This paper also analyzes the factors which determine attendance and participation in such meetings.

A worrisome feature of the results was the high proportion of married women reporting that they cast their vote according to their husbands' instructions and further that this proportion was impervious to the education level of the women. The results would suggest that the reservation of village panchayat positions (including that of panchayat pradhan or village president) for women was a step in the right direction for the empowerment of women. In contrast, there were no intersocial group differences in participation in Gram Sabha meetings.

8. "Elections with International Relations Dominance," Jan Klingelhöfer (RWTH Aachen University)

This chapter combines a model of international cooperation with a model of domestic politics with national elections between an incumbent prime minister and a challenger. International cooperation is modeled as a repeated prisoner's dilemma game between two countries who are represented by their prime ministers. I compare three types of equilibria. In the country-specific grim trigger equilibrium, domestic politics does not affect international cooperation, and the standard results for the repeated prisoner's dilemma game apply. The second equilibrium is based on McGillivray's and Smith's (2000) idea of agent-specific punishment. If a prime minister cares sufficiently about staying in office, the threat of replacing him in a primary if he does not cooperate internationally can change a politician's incentives and make a larger maximum equilibrium level of cooperation possible. In the third equilibrium, I introduce the new idea of international dominance. In this type of equilibrium, domestic politics are dominated by considerations of international relations. The only function of the elections becomes either to punish or reward the prime minister 
for international cooperation. Consequently, the maximum achievable level of international cooperation can be increased, but elections no longer lead to the victory of the candidate preferred by the representative voter.

9. "Electoral Rules and Proportionality in Spain: Estimating the Impact of Some Swedish Rules Through the 2011 Electoral Data," José M. Pavía and Fernando Toboso (University of Valencia)

As many contributions have shown, the share of seats that political parties get in all elections is partly influenced by the electoral rules in place and particularly by the specific rules influencing how votes get converted into seats. In Spain, a traditional complaint has existed by both the leaders and supporters of some statewide political parties (such as IU or UPyD) who systematically have got a much lower share of seats than their share in total popular votes. This nonproportionality is also evident if we compare the results traditionally obtained by these two small statewide parties with those obtained by nationalist parties such as PVN (Basque Country) or the, now broken, coalition called $\mathrm{CiU}$ (Catalonia) that only presents candidates at one region-state and not in all regions-states of Spain. As the Swedish electoral system is known as a quite proportional system that could be implemented in Spain without reforming the Spanish Constitution, the purpose of this chapter consists of estimating how much the share of seats that resulted from the 2011 Spanish general elections would change if we apply some Swedish basic rules upon the raw electoral data, ceteris paribus. Of course, the behavior of voters and members of political parties also matters, and this behavior is not independent of the existing electoral rules, so the purpose of the paper is not to provide predictions.

\section{Part III: State and Public Services}

10. “Is There a Doctor in the House?", Jani-Petri Laamanen, Mikko Poutanen, and Katri Sieberg (University of Tampere)

The option to purchase private health insurance in an otherwise public system seems to offer the best of all alternatives. The public system provides universal coverage, while the private option allows those with more resources to be able to purchase superior services. A closer look at the issue, however, reveals the potential for problems to arise in both the demand for the services and supply of the health-care professionals. We present a simple model of the incentives that the private sector can use to attract doctors in their choices between employment in the public and private sector. We further assess the resulting effects on doctor supply between the two sectors-in terms of numbers and in terms of quality. Our results indicate that without controls, the system can at best develop into a two-class system, in which more and/or better doctors select the private system, leaving inferior doctors in the public sector. As a real-world example of this problem, we appeal to the example of the Finnish health-care system, with its mixture of public and private services, and 
show how the increase in private coverage has been associated with a decrease in resources for the public system. Our results indicate that this hybrid system is harmful to societal goals.

11. "What Makes People Nursing Home Residents: Individual Need or Municipalities' Supply?", Theis Theisen (University of Agder)

In a setting where admissions to nursing homes are strictly rationed, we consider which individuals become nursing home residents. Rationing decisions are taken at the level of municipalities. Using a national sample, we examine the impact on the rationing decision of individual characteristics and characteristics of the municipalities in which individuals live. High age, lack of self-care functionality, and lack of cognitive ability have a positive impact on whether an individual is in a nursing home. Men have a slightly lower incidence of living in a nursing home than women. Municipalities' capacity in the nursing home sector has a strong positive impact on the probability of living in a nursing home.

12. "Civil Service and the Crisis: A comparative analysis of Iberian Countries (2008-2013)," Oscar Briones (University of Vigo), Joaquim Filipe Ferraz Esteves de Araújo (University of Minho), and Enrique J. Varela (University of Vigo)

The aim of this chapter is to assess the changing working conditions of public employees in order to shed some light on controversial issues concerning public employment models of central government in Spain and Portugal. The trends and reforms have been analyzed to assess the theoretical approaches underpinning policy reform implemented until the year 2013. In short, the aim of this study was to answer the question: Are reforms implemented due to the international financial crisis simply reforms and cuts in public employment, or do these changes entail a widespread far-reaching transformation in the current public employment models of the two Iberian states? Should the answer be the latter, this would signal the death of the civil servant as key actor of the human resource management model of the central government in Spain and Portugal.

\section{Part IV: Cases of Institutional Change}

13. "Congressional Negotiations with Costly Voting: Understanding the Reforms to PEMEX in 2006-2008," Gilles Serra (CIDE)

The state-owned petroleum company in Mexico has played a fundamental role in the economy, but its productivity has been worryingly in decline. Several presidents of Mexico before Felipe Calderón tried to modernize Pemex, but they failed to pass any meaningful legal reform through the Congress. In this chapter I explain why Calderón was successful where other presidents were not. At the same time, I explain why Calderón's successes were not as large as they could have been: indeed, the legal reforms to the Mexican oil industry in 2006-2008 were not as profound as they were expected to be. I claim 
this was due to the costs that political conditions imposed on congressional negotiations. Irrespective of their preferences, legislators faced punishment by radical political leaders and passionate voters if they supported Calderón's initiatives. At the same time, some pivotal negotiators in the Congress were able to extract significant side payments for their support of government initiatives. To clarify these complex dynamics, I use the traditional concepts from spatial voting theory: I identify the main issues regarding Pemex, the main political agents in charge of reform, and the positions of these agents on those issues. I also propose a modeling innovation to the traditional spatial theory of voting, which consists on considering the punishment that legislators may incur from supporting a bill that they like. With these theoretical tools, I am able to explain the puzzling coalitions that were formed for the 2006 budget law, the 2007 fiscal reform, and the 2008 energy reform. I suggest that these same theoretical tools could be used to understand congressional negotiations in other contexts.

14. "Institutional Change, Specific Investments and Photovoltaic Power Plants: The Empirical Effects of the Energy Policy of Solar Farms in Spain," Marcos Álvarez-Díaz, Raquel Fernández-González, and Gonzalo Caballero (University of Vigo)

The Spanish government introduced a bonus policy for the installation and exploitation of photovoltaic solar energy before the Great Recession, and it implied the increase of the number of solar farms in Spain. Nevertheless, the government did not adequately take into account the cost of the bonuses for the public treasury and neither did it contemplate the changing macroeconomic scenario derived from the Great Recession since 2008. In fact, the government rectified later and proceeded toward cancelation and elimination of the bonus policy in the photovoltaic sector. This chapter analyzes the process of institutional change and of bonus policies in the Spanish solar energy sector from the point of view of new institutional economics, by performing an empirical analysis on the effects of an energy policy that first announced and established public bonuses for solar parks but which later eliminated them unilaterally. These changes in energy policy had a significant impact on return for investors who had made irreversible investments in solar parks. The empirical analysis concludes the change in the trends of the Spanish solar farm sector in September 2008. The institutional analysis includes the study of the process of institutional change and the legal actions, appeals, and lawsuits that the investors presented at the third-party enforcement mechanisms.

15. "The Economic Effects of the Implementation of the Greek Adjustment Plan in the Great Recession," Inmaculada Carrasco (Castilla-La Mancha University), Carmen Córcoles (Castilla-La Mancha University), and John McCombie (Cambridge University)

In a situation of deep economic crisis such as the present one confronting some European countries, it is necessary to take measures to reduce the dangerous disequilibria that they face. The orthodoxy dictates that it is imperative to undertake strong fiscal consolidation to ensure a recovery in economic activity. The existing debate has tended to focus on the global analysis of such policies. 
As a contribution to this literature, in this chapter we provide a multisector and multiregional study of the effects of the fiscal adjustment implemented in Greece in 2012 using an input-output methodology. It allows us to trace the consequences of this fiscal policy for the different Greek economic sectors, as well as for the EU and the rest of the world. This is undertaken using the WIOD (World Input-Output Database). This study concludes that, far from leading to a revival in the Greek economy, the fiscal adjustment has led to a contraction in the health and public administration sectors, as well as the industrial sectors with the last leading to a greater downturn in the economy.

16. "E-procurement and Innovation in the Portuguese Municipalities: When Change is Mandatory," Luís Soares (Câmara Municipal de Castro Verde) and Adão Carvalho (Universidade de Evora)

Changing the traditional pattern of public procurement for an electronic paradigm is a radical innovation involving major organizational changes, the breaking up of traditional processes and practices, and the obsolescence of knowledge and skills. Going beyond the European Commission's recommendations, in 2009 Portugal pioneered in making e-procurement mandatory in the pre-award phase, in a European context of multiple technical standards and lack of interoperability of electronic platforms across the EU countries. Six years later, when the creation of a European e-procurement single market is a EU mission and a major legislative amendment is under way in Portugal, this study looks at the relationship between e-procurement and innovation in the Portuguese municipalities aiming to understand the extent into which the adoption of e-procurement embraced a real organizational change or, on the other hand, if it just represented a mere adaptation of the usual procurement practices. The study draws on data from an electronic survey to all municipalities in mainland Portugal, and the analysis is mainly descriptive and exploratory. The paradigm shift in public procurement involves major organizational changes, but overall, the results suggest that most municipalities do not have a clear understanding of the innovative scope (depth and diversity) implied by e-procurement. Eprocurement shows advantages over the paper-based model, but an unbalanced perception of the innovation dimensions has influenced the implementation of e-procurement and the degree of organizational change. 